219 (1989).

28）大井煡太，宮井良孝，加藤俊作，ケミカルエンジニアリ ング, 35, 151 (1990).

29) K. Ooi, Y. Miyai and S. Katoh, Sep. Sci. Technol., 21, 755 (1986).

30) Y. Miyai, K. Ooi and S. Katoh, Sep. Sci. Technol., 23, 179 (1988).

31）宮井良孝, 大井健太, 加藤俊作, 海水誌，42，114 (1988).
32) J. C. Hunter, J. Solid State Chem., 39, 142 (1981).

33) K. Ooi, Y. Miyai and S. Katoh, Solv. Extr. lon Exch., 5, 561 (1987).

34) K. Ooi, Y. Miyai, S. Katoh, H. Maeda and M. Abe, Bull. Chem. Soc. Jpn., 61, 407 (1988).

35) K. Ooi, Y. Miyai, S. Katoh, H. Maeda and M. Abe, Langmuir, 5, 150 (1989).

\title{
3 海洋エネルギーの変換
}

梶川武信

\section{1 海洋エネルギー}

海洋エネルギーの大部分は, 太陽エネルギーにその起 源を持っているが，あらわれるエネルギー形態により， Table 1 のように分類される。海洋温度差エネルギ一 は，表層温海水を高温源として 600 1000 m の水深の 深層冷海水を泠熱源とする熱エネルギーである．温度差

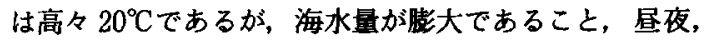
四季の別なく安定であることが大きな特徴である．波浪 は風により作られ，水粒子の回転運動エネルギーとなっ ている. パワー密度が我国治岸でも平均 $10 \mathrm{~kW} / \mathrm{m}$ と 大きいが, 変動も又大きいことが特徴である. 海流は直 進運動エネルギーで吹送流, 地衡流, 補流などによって 形成される、エネルギー変換システムのスケールにくら ベ, 流れの位置変動が大きい，潮汐及び潮流エネルギー は，地球一月一太陽系の運動から引きおこされ，地形に 大いに依存する，位置エネルギーとしての利用は，1966 年以来フランスのランス潮汐発電所で実用化されている. 塩分濃度差エネルギーは，海水中の塩分 $(1 \mathrm{~L}$ の海水に 塩分 $35 \mathrm{~g}$ を含む）と淡水（河川水）との間の塩分祳度 の差による化学ポテンシャルの差である. 生物エネルギー あ一種の化学エネルギーと考えられるが, これは海水中 の栄養塩と太陽エネルギーを用いて植物が光合成を行い， それを原料として炭化水素系に変換する. 海水中に溶け ているエネルギー物質を採取・回収するすのす海洋エネ ルギーの範囲に入れている.ただ，海底石油や石炭のよ うな化石燃料や海洋空間を利用した太陽エネルギーや風 カエネルギーの利用は海洋エネルギーには含められてい ないのが一般的である. Table 1 には，潜在的實源量， 水頭高さで表したエネルギー密度，変换原理式，及び工 学的によりあげられるようになったり提案された年代等 をまとめた。

海洋エネルギー全般にわたる共通的特徴は, (1)自然工 電子技術総合研究所（开305つくば市梅園 1-1-4）
ネルギーの希薄性（例えば海洋温度差発電で $1 \mathrm{~kW}$ 発電 電力を得るためには, 温海水と冷海水とが每秒 3 5L 必要となる位, 温度差エネルギーが小さいので量でそれ をまかなう必要がある.) (2)変動性（出力 $1 \mathrm{MWe}$ 級の 波力発電システム実験プラント「海明」では $125 \mathrm{~kW}$ の 発電機が 8 台搭載され, 最大值 $600 \mathrm{~kW}$ を得たものの奏 験条件の良い冬季であ平均は $100 \mathrm{~kW}$ と最大值の $1 / 6$ となっている.) (3)海洋は工学にとって厳しい罧境であ る.（台風による構造体への外力, 海水の持つ腐食性, 生物污れ, 高水圧, 光の非透過性, 海流による恒常的力, 波浪による動摇）等を挙げることができる、これらの特 徴を考虑し，あるあのは克服してエネルギー変换システ ムを桠築していかなければならず，陸上でのエネルギー 変換施設とは，非常に異なる技術的問題点を併せて考え ていかなければならない。

本解説では, 紙数の都合により複合化利用による実用 化への道が見通されるようになってきた海洋温度差発電

Table 1 Characteristics of ocean energy.

\begin{tabular}{|c|c|c|c|c|}
\hline $\begin{array}{l}\text { Energy } \\
\text { species }\end{array}$ & $\begin{array}{c}\text { Potential } \\
\text { resources } \\
\text { TW }\end{array}$ & $\begin{array}{c}\text { Energy } \\
\text { density } \\
\text { (Head : } \mathrm{m} \text { ) }\end{array}$ & $\begin{array}{l}\text { Energy } \\
\text { conversion } \\
\text { equations }\end{array}$ & $\begin{array}{c}\text { Invented or } \\
\text { denmonstration } \\
\text { date }\end{array}$ \\
\hline Ocean thermal & 2.0 & 210 & $\begin{array}{l}P=\eta_{\mathrm{R}} C G \delta T(W) \\
\eta_{\mathrm{R}}: \text { Rankine Eff. } \\
C: \text { Heat capacity } \\
\delta T: \text { Temp. Difference } \\
G=\text { Flow rate }\end{array}$ & 1881 \\
\hline Wave & 2.7 & 1.5 & $\begin{array}{l}P \sim H^{2} \mathrm{~T}(\mathrm{~kW} / \mathrm{m}) \\
H: \text { Wave height }(\mathrm{m}) \\
T: \text { Wave period }(\mathrm{s})\end{array}$ & 1898 \\
\hline Current & 0.05 & 0. 05 & $\begin{array}{l}P=\rho U^{3} / 2(\mathrm{~W}) \\
\rho: \text { Density }\left(\mathrm{kg} / \mathrm{m}^{3}\right) \\
U ; \operatorname{Velocity}(\mathrm{m} / \mathrm{s})\end{array}$ & \\
\hline \multicolumn{5}{|l|}{ Tide } \\
\hline (Tidal current) & 0.03 & $4 \sim 10$ & $\begin{array}{l}P=W g h(W) \\
W: \text { Flow rate } \\
h: \text { Head }\end{array}$ & 1044 \\
\hline $\begin{array}{l}\text { Salinity } \\
\text { gradient }\end{array}$ & 2.6 & 240 & $\begin{array}{l}P=\pi G(W) \\
\pi: \text { Osmotic pressure } \\
G: \text { Flow rate }\end{array}$ & \\
\hline Biomass & 10 & $10^{4} \mathrm{kcsl} / \mathrm{m}^{2} \mathrm{Y}$ & $\begin{array}{l}\text { Methane } \\
\text { Fermentation }\end{array}$ & \\
\hline $\begin{array}{l}\text { Dissolved } \\
\text { uranjum }\end{array}$ & $4 \times 10^{9}$ ton & $20.43 \mathrm{kcal} / 1$ & & 1956 \\
\hline
\end{tabular}


と電気化学分野に最す関係があると考えられる塩分袽度 差発電について概説することにした.

\section{2 海洋温度差エネルギーの交換}

海洋温度差発電システム㹥，(1温海水之冷海水を用い て有勃エネルギーをとり出すエネルギー変換システムと, (2)海水の取排水や発電システムを洋上又は陸上で格納す るための容器としての海洋構造物システムとに大別され る.ここでは，前者にウエイトを置き，高々 $20^{\circ} \mathrm{C}$ 前後 の温度差である低密度エネルギーの变换方式として，(1) クローズドランキンサイクルと(2)オープンランキンサイ クルを代表例としてとりあげ，その後，海洋温度差発電 の実用化へのアプローチとして近年注目をあびている OTECトータルシステムについて概説する.

\section{1 クローズドランキンサイクル}

熱機関を用いて有効エネルギーに変换する場合の理想 エネルギー变換効率はカルノー効率であるが, 海洋温度 差エネルギー源（海水が熱の荷体であり，且つ温度差が 小さい）に䭂和ランキンサイクルを適用するとその効率 はカルノ一効率の 90 95\%を達成できる. 飽和ランキ ンサイクルを適用する場合に，2つの方式があり，1つ は，本節でとりあげるクローズドサイクルであり，他は， 次節で説明するオープンサイクルである.

Fig. 1 にクロースドランキンサイクル海洋温度差発 電の原理的ブロックダイヤグラムと典型的な場合の温度 配分の例を示した ${ }^{1)}$.クローズドサイクルでは，低沸点 媒体に温海水加ら隔壁型蒸発伝熱面を通して熱を与え， 的和蒸気を作る (等温膨張過程)，高圧となった蒸気は， タービンにおいて㜆張し，外部に有効仕事を与える（断 熱膨張過程). 仕事をした蒸気は凝縮伝熱面を介して,

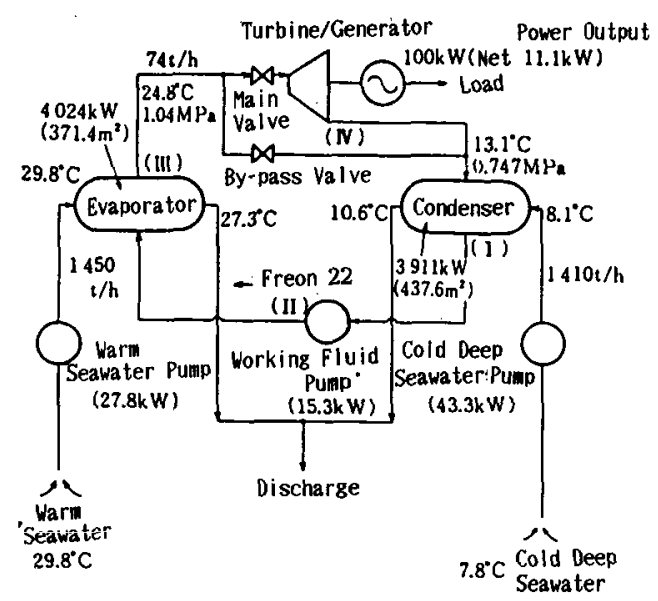

Fig. 1 Closed Rankine cycle OTEC system and an example of temperature \& mass flow allocations.
冷海水に凝縮潜熱を放出し，凝縮・液化する（等温圧縮 過程). 液体の作動流体は, 再循環ポンプにより加圧さ れ蒸発器に送り返され（断熱压縮過程），閉ループを形 成しサイクルを繰り返す，クローズドサイクルでは，(1) 低沸点媒体としての作動流体の選定と(2)海水の持つ温度 差エネルギーを效率的に作動流体に与える熱伝導の高性 能化が重要な問題となっている.

作動流体に望まれる特性として, Table 2 のように まとめられ2)，主な物性值が Table 3 に示されている。 又, 全体システムのコスト評価から, 作動流体のランク 付けあなされている。経済性，安全性の他に，発電規模 発電システムの立地点の社会的環境条件及び自然環境へ のインパクトの最小化といった諸条件を考虑した選定が 必要である.アンモ二了は第 1 候補として挙げられてい るが，取扱上の難点があるなど必ずしも完全とはいえな い. 特定フロン系は, 地球的規模の環境問題加らの見直 しが必要であり，今後ともより良い作動流体開発の努力 が望まれる。

海洋温度差発電での潜在的理想エネルギー変換効率は 温海水之冷海水の温度を基䃈にして導入される. $20^{\circ} \mathrm{C}$ の 温度差とすると約 $6.6 \%$ となる。 しかし，現実には，海 水の持つエネルギーを作動流体に与えるため, 熱の流れ を作る必要がある．熱源 $Q$ は， $Q=U A \theta （ U:$ 総括熱 伝達係数, $A$ : 伝熱面積, $\theta$ : 対数平均温度差与海水の 入口と出口の平均温度と作動流体の温度差との差）によっ て表されるように，その駆動力としてある温度差が必要 となる．通常全体温度差の半分近くがそれに費やされ， カルノー効率で考えても約 $3.3 \%$ となっしまう。

Table 2 Selection condition of working fluids.

1. Primary properties

- proper boiling temperature

- proper critical temperature

- the melting point is not too high

- large molecular weight

- small number of atoms per mole

- the pressure is not too high for the utilized temperature

2. Thermodynamic properties

- large enthalpy drop at the turbine

- small latent heat

- large heat capacity of liquid phase

- the gradient of saturate in curve at FS diagram is rather regative

3. Chemical properties

- stable to thermal process

- small solvility to water, oil and gas

- inactive and less corrosive

- not inflammable

- not toxic

- self-lubricative

4. Transport properties

- large thermal conductivity

- small viscosity of liquid phase

- large mass density of liquid phase

- small specific volume of gas phase

5. Availability

- stable supply and low cost

- high purity working fluid can be easily available

- small environmental impact 
Table 3 Representative properties of low-boiling-point working fluid.

\begin{tabular}{|c|c|c|c|c|c|c|c|}
\hline Material & $\begin{array}{l}\text { Molecular } \\
\text { formula }\end{array}$ & $\begin{array}{c}\text { Molecular } \\
\text { weight } \\
\text { M }\end{array}$ & $\begin{array}{l}\text { Boiling } \\
\text { point } \\
\text { Tb(K) }\end{array}$ & $\begin{array}{c}\text { Melting } \\
\text { point } \\
\operatorname{Tm}(\mathrm{K})\end{array}$ & $\begin{array}{l}\text { Critical } \\
\text { Temp. } \\
\text { Tc(K) }\end{array}$ & $\begin{array}{l}\text { Critical } \\
\text { Pressure } \\
\text { Pe(MPa) }\end{array}$ & $\begin{array}{r}\text { Critical } \\
\text { Density } \\
\mathrm{P}\left(\mathrm{kg} / \mathrm{m}^{3}\right)\end{array}$ \\
\hline Water & $\mathrm{H}_{2} \mathrm{O}$ & $18 . \overline{015}$ & 373.15 & 273.15 & 647.30 & 22.10 & 320 \\
\hline $\begin{array}{c}\text { Ammonia } \\
\text { Carbon }\end{array}$ & $\mathrm{NH}_{3}$ & 17.030 & 239.8 & 195.4 & 405.45 & 11.27 & 235 \\
\hline dioxide & $\mathrm{CO}_{2}$ & 44.010 & 194.8 & 216.6 & 304.3 & 7.37 & 468 \\
\hline Helium & $\mathrm{He}$ & 4.003 & 4.25 & - & 5.25 & 0.229 & 69.3 \\
\hline $\mathrm{R}-11$ & $\overline{\mathrm{CCl}}{ }_{3} \mathrm{~F}$ & 137.368 & 296.92 & 162.0 & 471.2 & 4.41 & 554 \\
\hline $\mathrm{R}-22$ & $\mathrm{CHClF}_{2}$ & 86.469 & 232.33 & 113.2 & 369.30 & 4.99 & 513 \\
\hline R-113 & $\mathrm{CCl}_{2} \mathrm{~F}-\mathrm{CCl} \mathrm{F}_{2}$ & 187.376 & 320.72 & 240.2 & 487.30 & 3.41 & 570 \\
\hline$R-114$ & $\mathrm{CClF}_{2}-\mathrm{CClF}_{2}$ & 170.922 & 277.0 & 105.2 & 418.7 & 3. 26 & 582 \\
\hline$R-13 B 1$ & $\mathrm{CBrF}_{3}$ & 148. 910 & 215.40 & 105.2 & 340.2 & 3.96 & 745 \\
\hline Methane & $\mathrm{CH}_{4}$ & 16.043 & 111.66 & 90.39 & 190.55 & 4.60 & 162 \\
\hline Propane & $\mathrm{C}_{3} \mathrm{H}_{8}$ & 44. 096 & 231.08 & 85.46 & 369.95 & 4. 24 & 220 \\
\hline n-Butune & $\mathrm{C}_{4} \mathrm{H}_{10}$ & 58.123 & 272.65 & 134.9 & 425.2 & 3.79 & 228 \\
\hline Ethylene & $\mathrm{C}_{2} \mathrm{H}_{4}$ & 28.054 & 169.5 & .104 .2 & 282.5 & 5.11 & 229 \\
\hline
\end{tabular}

温度差 $\theta$ は $A$ や $U$ に関係し， $A$ は材料費，Uは材料加 工費などコストに影響を与えるため，単純に $\theta$ を小さく すれば良いという訳にはいかず，技術て解決できる点は $U$ と $A$ ということになる．総括熱伝達俰数 $U$ は，作動 流体側 (蒸発及び嬁縮)，伝熱材料，海水側（強制対流 熱伝達，生物污れ）の各部の高性能化が必要となる。蒸 発・沸騰熱伝達の高性能化には，金属多孔質層の形成や リエントラントキャビテイを微細加工によって作る加工 面が核沸騰域の高性能化として提案され，実証されてい る ${ }^{3)}$. 今後は，更に小さい温度差で高い熱流束を効率的 に得るため, 表面蒸発域での薄膜的蒸発を乾き面を出さ ない条件で達成していく構造が求められよう．凝縮熱伝 達の高性能化は，薄膜化を指導原理として各種構造が実 証されたが，更に高性能化を達成するには，すでに従来 から研究がなされている滴状数縮面の実用化が必要であ ると思われる．海水側の生物污れに関しては，実海域実 験がハワイ, ナウル, 徳之島, 富山湾で行われデータが 蓄積されてきている. 樑層海水は清浄であり, クリーニ ング設備は不要であるが, 表層海水には不可欠である. クリーニングシステムに対する海洋温度差発電の問題と しては，(1)偯境や生物生産性向上システムとの両立性， (2)補機動力最小化，(3)伝熱促進のための加工面との両立 性を図っていかなければならない。

伝熱面材料は現時点では，コストあ下がってきたチ夕 ンが信頼性の上から採用される.コストをさらに下げる 可能性のあるものとしては，モジュール化されたアルミ プレートフィン熱交換器があるが, 信頼性, 運用法につ いての検討が必要である.

\section{2 オープンランキンサイクル}

オープンサイクルは, クローズドサイクルと原理的に は同じであるが，低沸点媒体を用いず直接海水を作動流 体とするところが異なっている.クローズドサイクルで

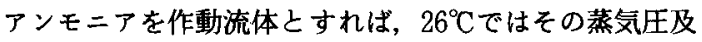

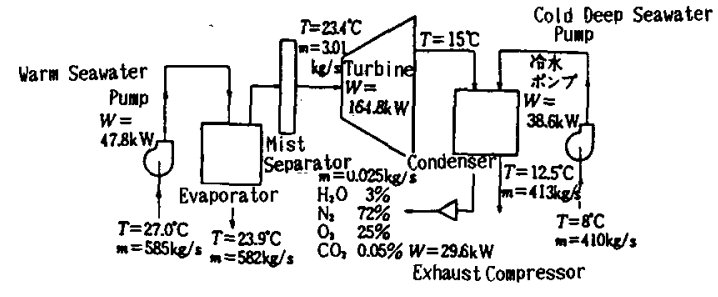

Fig. 2 Open Rankine cycle OTEC system and an example of temperature \& mass flow allocations.

び体積密度は, $1.054 \mathrm{MPa}$ 及び $8.03 \mathrm{~kg} / \mathrm{m}^{3}$ であるが, オープンサイクルで海水（水）を用いる之，その各々は $3.424 \mathrm{kPa}$ 及び $0.02437 \mathrm{~kg} / \mathrm{m}^{3}$ となり，オープンサイ クルでは非常に動作圧力の低い状態でシステムを稼動さ せなければならない。

Fig. 2 にオープンサイクルの主要コンポーネントと 温度配分の一例を示した ${ }^{4)}$. 温海水は蒸発器内で自分自 身の熱で海水の約 $0.5 \%$ 蒸発させ，作動流体之する. タービンの入口々出口の間の蒸気圧力差は, 僅か約 1.5 $\mathrm{kPa}$ である. 仕事を終えた水蒸気は冷海水之值接接触 凝縮を行う。このようにオープンサイクルの特徽は，(1) 作動流体が無公害な水であること, (2)蒸発器内ではフラッ シュ蒸発, 凝縮器では直接接触とチタンのような高価な 伝熱材料が不要であること, (3)従って全体温度差の内有 効仕事へ割りふる温度差を大きくとれるため原理的には 効率が高くなる．(4)動作圧力が低いため体積当たりの出 力が小さい，従っておまり大規模発電には適していない． (5)海水中の溶存ガスの蒸発器の中で系内に入り込み, 系 内に不凝縮ガスとして性能の低下を引きおこす, 又, 炭 酸ガスが僅かではあるが深層海水から放出される.

オープンサイクルの中核技術は，海水中の溶存気体の 振舞いを考虑に入れた蒸発及び疑縮装置にある。蒸発方 

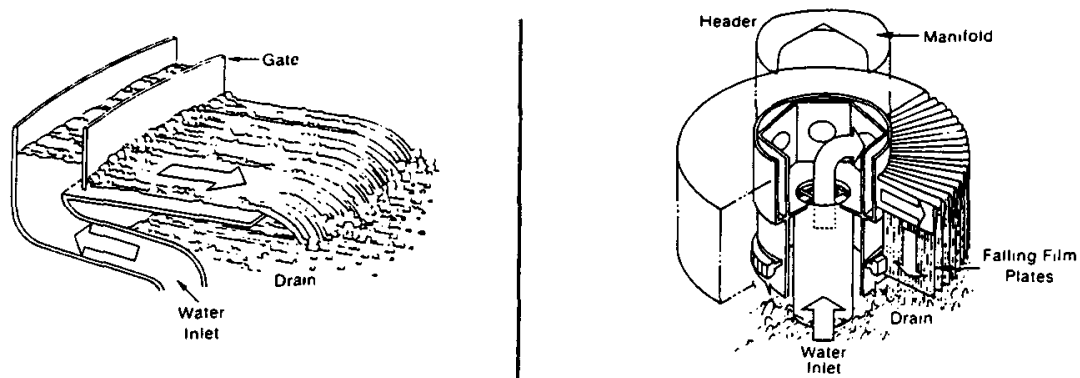

(2) Falling Films
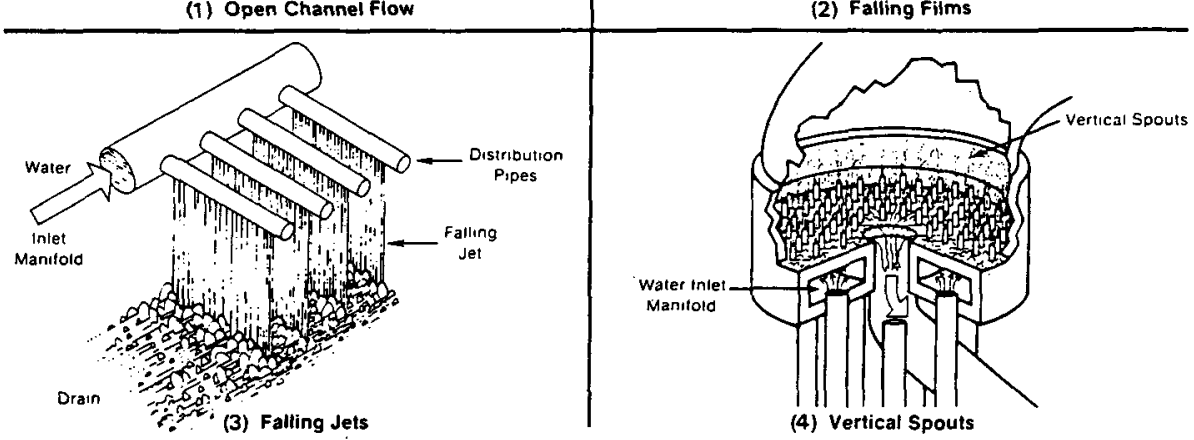

Fig. 3 Examples of evaporator for open cycle OTEC system.

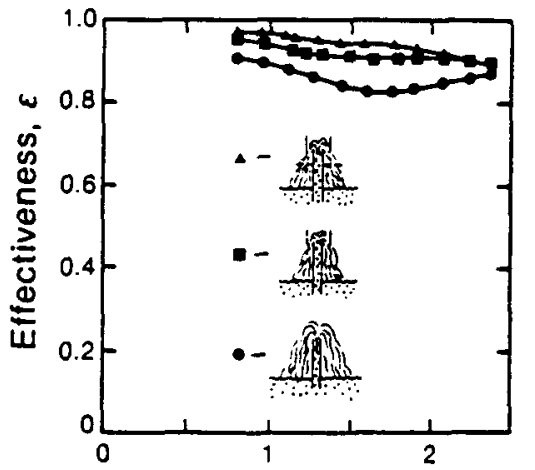

Water Inlet Velocity, Uo $(\mathrm{m} / \mathrm{s})$

Fig. 4 Performance of spout type evaporator.

式は，海水淡水化で用いられているオープンチャネルフ ラッシュ蒸発の他 Fig. 3 に示すような方式がある．低 圧力損失下での効率的蒸発が必要である．アメリカ太陽 エネルギー研究所（SERI）では，Fig.4中(4)の嗔流型 （スパウト型）が良いことを小型模擬システムで実証し た. Fig. 4にその結果の一列を示した5).

性能を表す温度利用率 $\left[=\left(T_{\mathrm{HI}}-T_{\mathrm{HO}}\right) /\left(T_{\mathrm{HI}}-T_{\mathrm{E}}\right)\right]$ はスクリーンを入れる工夫をすることによって $0.7 \mathrm{~m}$ の水頭損失（高さ損失及び運動エネルギー損失）の下で 0.90〜0.97を達成している.

直接接触綵縮器は熱伝達之共に低圧力損失の下で効率

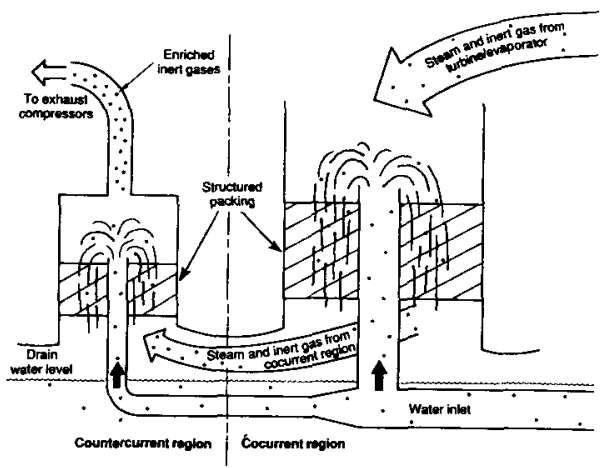

Fig. 5 Concept of two stage type direct contact condenser for open cycle OTEC system.

的に不凝縮ガスを排除することが求められる．Fig. 5 には概念的な 2 段の直接接触凝縮を示しているが，不凝 縮ガスを含む直接接触凝縮熱伝達でのある程度のスケー ルを持った場合の挙動についてはまだ不明な点が多く, 性能を高い精度で示すことができない，各種の形状を持 たせた詰め物によって，互いの接触を効果的に行う研究 が行われている.

オープンサイクルの蒸気には塩分を含まないため，隔 壁型凝縮器で凝縮させれば，淡水を得ることができると いう副産物のメリットがある，隔壁型凝綟之直接接触凝 縮器とを組み合わせた疑縮装置が実用的スケールでは考 


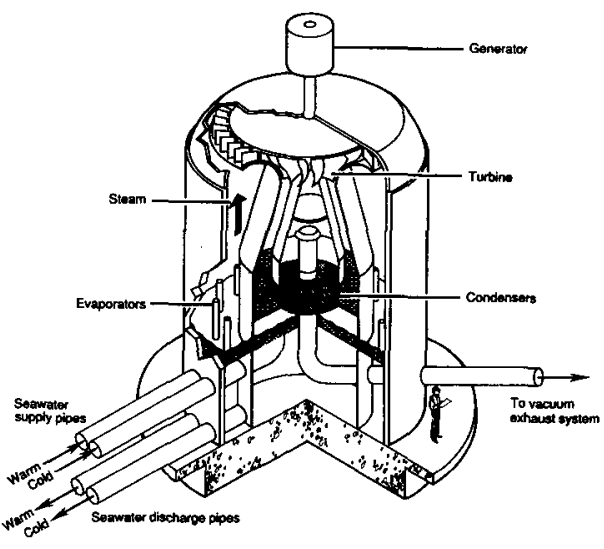

Fig. 6 Concept of $165 \mathrm{kWe}$ gloss open cycle OTEC pilot plant $(7.0 \mathrm{~m}$ height $\times 6.5 \mathrm{~m}$ Diameter $)$.
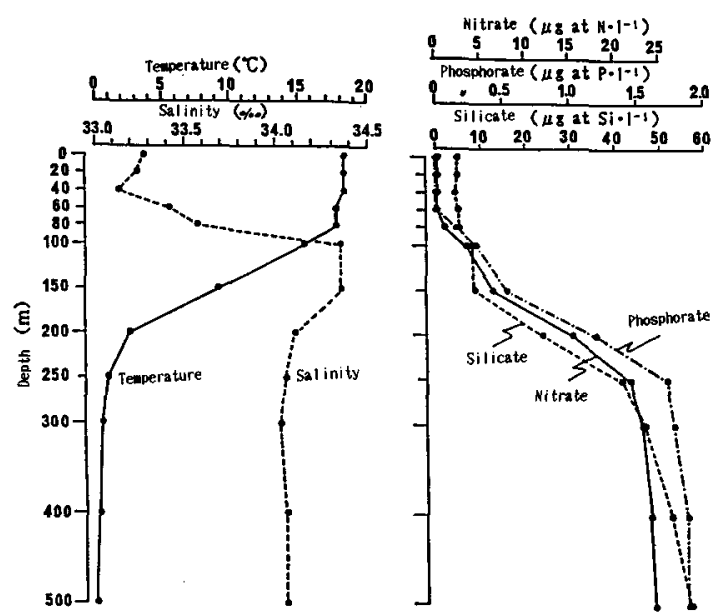

Fig. 7 Concentration profiles of inorganic nutrients in depth (Toyama Bay, the Sea of Japan).

えられる，ハワイ島で 1992 年稼動を目指し，正味出力 を取り出す初のオープンサイクル実験装置として提案さ れている概念図をFig. 6 に示した。 総出力 $165 \mathrm{kWe}$, 正味出力約 $48 \mathrm{~kW}$ が考えられている.

\subsection{OTEC トータルシステム}

海洋温度差発電で冷熱源としての役割をはたす泠海水 は，水深 $600 \sim 800 \mathrm{~m}$ から取水管を通じて取得される. 冷水取水管は発電出力 $1000 \mathrm{~kW}$ クラスでは直径 $2 \mathrm{~m}$ 前 後となり，その設備及び敷設は現状技術を超える部分が 多く，コスト低減への大きな障害となっている。一方, 深層水は，低温であるばかりでなく，Fig. 7 の例にみ られるごとく無機栄養塩（硝酸塩，リン酸塩ケ㯰塭） が豊富であり，又，バクテりア等が非常に少ない清浄な

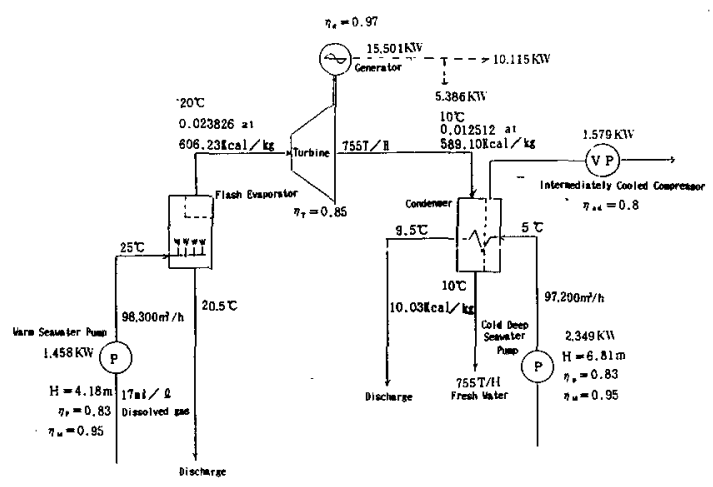

Fig. 8 Open cycle system combined with disalination system.

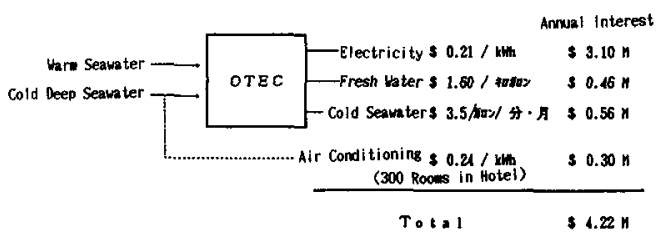

Fig. 9 Estimation of annual interest for 1.5 MWe OTEC total system.

海水である．深海水のこのような特性を利用して，発電 ばかりでなく他の高い価値を作り出すことによって, 経 済性をトータルとして達成しようとする考えが OTEC トータルシステムである．低温性を利用した空調・低温 眝蔵及び淡水化と富栄養塩・清净性を利用した水産養殖 が提案されている. Fig. 8 に $10 \mathrm{MWe}$ オープンサイク ルと淡水化プラントとの結合例を示した，オープンサイ クルでは，凝縮器の一部又は全部を隔壁型凝縮器とする ことで，そのまま淡水を得ることができる．水産善殖で は, 陸上に養殖池を作りケルプ，八リ，微細藻類，アワ ビ，カキ，ロブスター，ウニ, ニジマス，ギンザケ等が 研究され，ハワイではアワビは実用化している．基礎的 研究により，栄養塩の効果の定量化や，沿岸海域の利用 の検討がすすんでいる. Fig. 9に, 1.5 MWe OTECトー タルシステムからの利益見積りの例を示した。冷水は, 水産養殖用として販売することによる利益であり，それ を用いて養殖を行った結果の利益ではない，この例では， 電力単位にくらべ利益は 1.36 倍となっている，立地点 によっては, 淡水価値が大きく変動したり, 空調需要と して近くホテルがあることなど, トータルシステム化に 付随した技術以外の要素が入ってくることを実用化にあ たっては考慮しなければならない。 


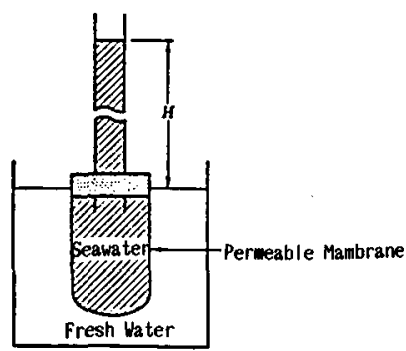

Fig. 10 Osmosis phenomenon.

\section{3 塩分㴤度差エネルギーの変換}

塩分濃度差発電とは，海水之淡水之の間の塩分洤度の 差, すなわち両者の化学ポテンシャルの差を電力などの 有効エネルギーに変換する技術である.

塩分濃度差エネルギーの主な変換方式には, (1)浸透圧 利用と, (2)濃淡電池がある.

\section{1 漫透圧利用塩分灌度美発的}

水分子は通るが塩化ナトリウムのような塩分の拡散を 許さない選択性を持った膜 (membrane) は，半透過 （Semi-permeable）膜と呼ばれている.この膜を Fig. 10 の上うに海水之淡水との間に張ると，淡水が海水側 に拡散しある高さ $\mathrm{H}$ まで押しあげる. 圧力について平 衡点に達し, 浸透現象が止まった時の海水の淡水に対す る圧力が浸透圧 (osmotic pressure) と呼ばれるもの である.

平均的海水（塩分 35）の淡水に対する浸透圧は温度 $20^{\circ} \mathrm{C} て ゙ 2.48 \mathrm{MPa}$ （水頭にして $256.2 \mathrm{~m}$ ）に達する. 浸 透压は，塩分と温度の関数で表される．温度 $T\left({ }^{\circ} \mathrm{C}\right)$ の 浸透圧 $\pi_{0}(\mathrm{~atm})$ は, 水点降下 $T_{g}\left({ }^{\circ} \mathrm{C}\right)$ を用いて次式 で表される.

$$
\pi_{\mathrm{o}}=-12.08 T_{\mathrm{g}}(1+T / 273.15)
$$

氷点降下 $T_{g}$ は塩分 $S$ と次式の関係で近似的に表される.

$T_{\mathrm{g}}=-0.003-0.0527 S-0.00004 S^{2}$

この浸透圧を利用してタービンを回し有効動力を得るの であるが，その海水側の圧力をどう保つかによって発電 方式が分類される．すなわち，

1）海水をポンプによって加圧供給する海水加圧方式

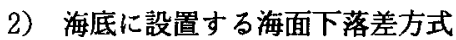

3）クローズドループへの浸透圧による圧力上昇を利用

した自己加圧方式

の3つに大別される.

1）の方式の原理を H'ig. 11 に示す。海水を動作圧力 $\pi$ まで加圧して浸透装置に送り込み，淡水は半透膜加ら 流量 $Q_{0}$ で浸透し, タービンを回して発電出力 $P_{\mathrm{i}}$ を得る 正味出力 $P_{\mathrm{n}}$ は，この出力から海水及び淡水各々のポン プ動力 $P_{\mathrm{c}}, P_{\mathrm{a}}$ を差し引いたものとなる。

$$
P_{\mathrm{n}}=P_{\mathrm{i}}-\left(P_{\mathrm{c}}+P_{\mathrm{a}}\right)
$$

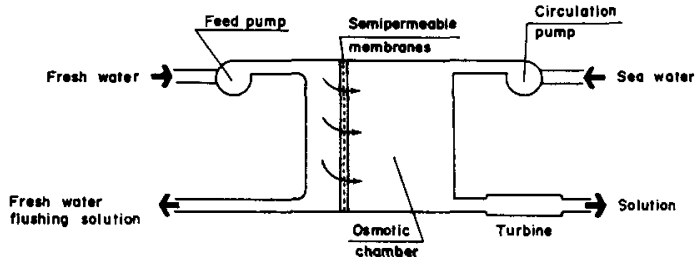

Fig. 11 Pressurized seawater type pressureretarded osmosis energy conversion system.

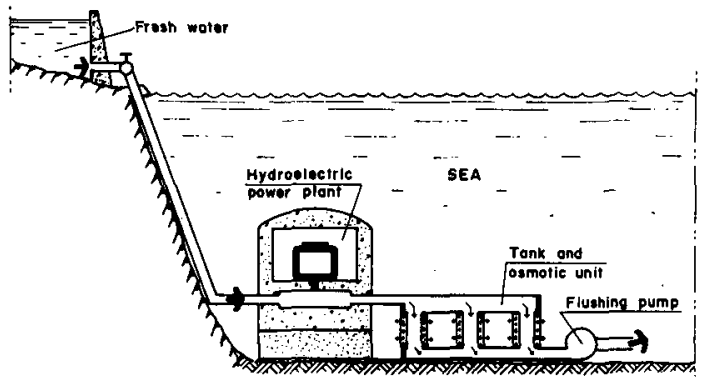

Fig. 12 Submarine type pressure-retarded osmosis energy conversion system.

$P_{\mathrm{i}}=\pi Q$ 。

ただし，

$$
Q_{\mathrm{o}}=K_{\mathrm{m}} A\left(\pi_{\mathrm{o}}-\pi\right)
$$

$K_{\mathrm{m}}$ は膜の性能係数, $A$ は膜面積である.

$\pi=\pi_{\circ} / 2$ の時の出力最大が得られるので, 最大効 率は $50 \%$ となる， $P_{\mathrm{c}}, P_{\mathrm{a}}$ の合計は $P_{\mathrm{i}}$ の半分位必要と なるため，この方式の最大効率は〜25\%となる，実際に は夕ービン效率，発電機效率が 1 以下なのでさらに效率 は低下する。

2）の海底設置方式は，設備を $100 \mathrm{~m}$ 程度の水樑の海 底に設置し, 水力発電と同様に海面から海底までの落差 を利用して淡水を落下させてタービンを回転し，発電さ せるあので, Fig. 12 にその様子が示される ${ }^{6)}$. タービ ン出口の淡水は浸透装置で海水側の水压に逆らって浸透 圧作用で排出する。 それ故タービン出口圷力を大気圧程 度に保っことができる。しかし，淡水の一部を浸透装置 の性能低下防止のためフラッシングし，それをポンプて 排出してやることが必要となる。この方式は，前の方式 より理想的には〜 50\%の变換効率を持っていることがわ かる．海底には機器を設置するための工事や保守に問題 があるが，高圧で運転されるタービンは，淡水中での回 転であるため腐食等の心配が少なくなる。

3）の方式は，海水で満たされたタンクに浸透装置を 介して淡水を接続すると，浸透水により，タンク内の圧 力が上昇する．この囘力を利用してタービンを回転させ 発電出力を得る. Fig. 13 にその原理を示した ${ }^{7}$. 浸透 


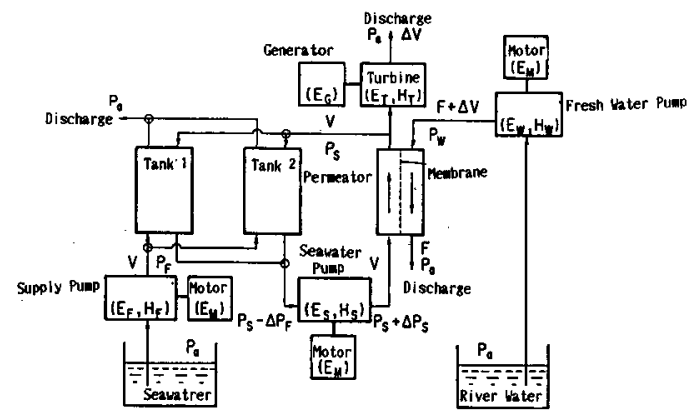

Fig. 13 Alternative tank type pressure-retarded osmosis energy conversion system.

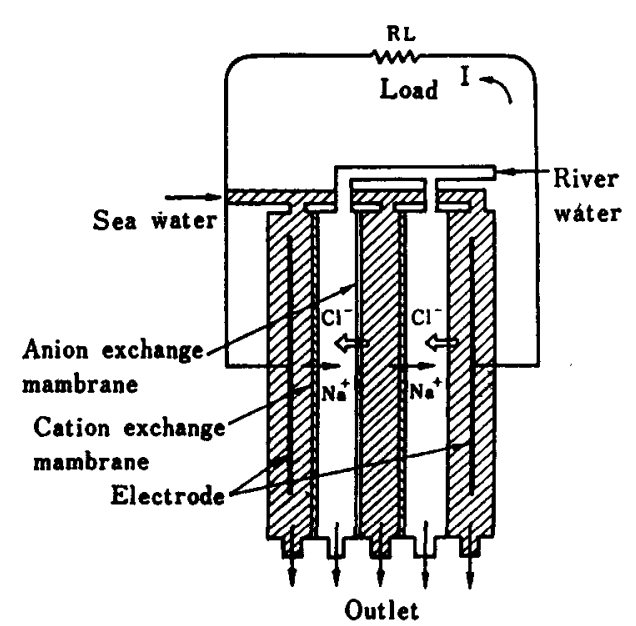

Fig. 14 Concentration cell type salinity gradient power generation system.
装置から出てくるうすめられた海水の内, 浸透水流量分 のみがタービンに送られる.タンクに戻された希釈海水 は, 海水と混合しないように戻されて排出され，その分， タンクの海水が減少する. 界面がタンク下限に達した時, 別の海水充填済みのタンクと切り换元発電を連続的に行 う. 海水循環ポンプ, 淡水循環ポンプは流路の圧力損失 程度で動作するためポンプヘッドが小さくてよい，それ 故, 補機動力が少なくてすむこと及び海底装置にくらべ， 陸上に設置できるという利点がある. Table 4 に同一 の浸透装置を用いた海底設置式とタンク切り換元式の奏 験と計算結果の例を示した ${ }^{7)}$.

浸透装置の中核となる膜については，海水淡水化シス テムのるのが利用されている．M. Reali らは，中空織 維（酢酸セルロース系及びポリアミド）及びスパイラル （酢酸セルロース）を用いて実験を行い ${ }^{8)}$ ，本多は中空 織維（酢酸セルロース）を用いたが従来型のエレメント 内部訨切りを 4 分割から 2 分割にすることにより同一エ レメントでの有効膜面積を $66 \%$ 增加させ, 比出力の改 善をはかった.

\section{2 浽淡自池型塩分浽度差発自}

海水と淡水の塩分浱度の差による化学ポテンシャルの 差を濃淡電池の原理を用いて電力に変換する方式でおる. その原理的な構成を Fig. 14 に示す. 本方式は可動部分 がなく構造が簡単であるが, 海水, 淡水をセル内に送り 込むためのポンプが必要で, 浸透圧方式と異なりこのポ ンプ動力は回収できない. 電圧はギブスの自由エネルギー を基礎にして，例えば海水側塩分 35 ，淡水側塩分を 0.015 とすると起電力は $0.104 \mathrm{~V}$ が得られる. 電流を確 保するためには，淡水側及び各イオン交換膜の抵抗を下 げる必要がある，低内部抵抗型電池とすることは，淡水 に尊電性を持たせることで塩分濃度差のポテンシャルの

Table 4 Comparison of alternative tank type with submarine type pressure retarded osmosis energy conversion system.

\begin{tabular}{|c|c|c|c|c|c|c|c|c|c|c|c|c|}
\hline \multirow{2}{*}{$\begin{array}{l}5130 \text { type } \\
\text { permeator } \\
2 \mathrm{p}: \text { two- } \\
\text { partitioned }\end{array}$} & \multirow{2}{*}{$\begin{array}{c}\text { Membrane } \\
\text { Area } S \\
\left(\mathrm{~m}^{2}\right)\end{array}$} & \multirow[b]{2}{*}{$\begin{array}{c}\text { Supply. } \\
\text { Ratio } \\
\mathbf{x} \\
{\left[\frac{\mathrm{V}}{\triangle \mathrm{V}}\right]}\end{array}$} & \multirow[b]{2}{*}{$\begin{array}{c}\text { Flashing } \\
\text { Ratio } \\
f \\
{\left[\frac{F}{\Delta V}\right]}\end{array}$} & \multirow[b]{2}{*}{$\begin{array}{c}\text { Net } \\
\text { Power } \\
\text { Output } \\
\text { W } \\
{[\mathrm{W}]}\end{array}$} & \multicolumn{2}{|c|}{ Specific power } & \multirow[b]{2}{*}{$\begin{array}{c}\text { Pressure } \\
\text { Difference } \\
\Delta \mathrm{P} \\
{[\mathrm{atm}]}\end{array}$} & \multirow[b]{2}{*}{$\begin{array}{c}\text { Permeated } \\
\text { Flow Rate } \\
\triangle \mathrm{V} \\
{\left[\frac{\mathrm{m}^{3}}{\mathrm{~h}}\right]}\end{array}$} & \multicolumn{2}{|c|}{ Pressure Loss } & \multirow[b]{2}{*}{$\begin{array}{c}\text { Mechanical } \\
\text { Efficiency } \\
E_{\text {om }} \\
{[\%]}\end{array}$} & \multirow[b]{2}{*}{$\begin{array}{c}\text { Energy } \\
\text { Conversion } \\
\text { Efficiency } \\
E_{o c} \\
{[\%]}\end{array}$} \\
\hline & & & & & $\begin{array}{c}\text { per } \\
\text { membrane } \\
\text { srea } \\
{\left[\frac{\mathrm{W}}{\mathrm{m}^{2}}\right]}\end{array}$ & $\left.\begin{array}{c}\text { per fresh } \\
\text { water flow } \\
\text { rate } \\
{\left[\frac{\mathrm{kWh}}{\mathrm{m}^{3}}\right.}\end{array}\right]$ & & & $\begin{array}{l}\Delta \mathrm{P}_{s} \\
{[\mathrm{~atm}]}\end{array}$ & $\begin{array}{l}\Delta \mathrm{P}_{\mathrm{w}} \\
{[\mathrm{atm}]}\end{array}$ & & \\
\hline Alternative & & & & & & & & & & & & \\
\hline $\begin{array}{c}\text { Tank Type } \\
(2 \mathrm{p})\end{array}$ & 14. & 5.04 & 1.09 & 6.7 & 0.48 & 0.088 & 12.2 & 0.0361 & 0.09 & 0.46 & 54 & 11.2 \\
\hline Calculation & & & & & & & & & & & & \\
\hline Experiment & 16.6 & 3. 48 & 0.91 & 8. 2 & 0.49 & 0.108 & 11.9 & 0.0397 & 0.16 & 0.27 & 59 & 13.7 \\
\hline Submarine & & & & & & & & & & & & \\
\hline $\begin{array}{l}\text { Type (2p) } \\
\text { Calculation }\end{array}$ & 14 & 6.44 & 0.55 & 6.6 & 0.47 & 0.106 & 10.7 & 0.0396 & 0.12 & 0.33 & 55 & 13.5 \\
\hline Experiment & 16.6 & 3.90 & 0.49 & 7.9 & 0.48 & 0.107 & 10.1 & 0.0484 & 0.27 & 0.25 & 55 & 13.9 \\
\hline
\end{tabular}


一部を儀性にする必要があるなど問題点が多く，現状で はかなり難しいと思われる。

\section{4 おわりに}

発電技術はシステム技術であるといえる部分が多いが， 研究開発レベルでは，システム技術と要素技術は，半々 のウエイトを占放でぎあると思う，システムのブレー クスルーは，要素技術のブレークスルーからであり，そ の出発点は材料や現象を目的に結びつけたときに起こる と思われる. 電気化学は, 海洋エネルギー技術の中では まだ十分に活用されているとはいえない，海洋罢境は， 単に熱の荷体や水粒子の運動や塩分として単独に存在し ているのではなく，その中には，大小の生物，微粒子， 種々の化学物質更に，深海環境では，高水圧環境といっ た複合的要素を持った場としてとらえる必要があり，海 洋からの発想に立った電気化学が, 将来新しいシステム
の構築へのきっかけとなることを期待したい．

\section{文 献}

1) T. Mistui, F. Ito, Y. Seya, Y. Nakamoto, ASME 8 $3 \mathrm{WM}, 212-8$ (1983).

2）中本泰發，寺山俊郎，関矢英士，第 30 回電源開発機器研 究会, 5-1 5-60 (1983).

3）海洋エネルギー研究室, 電総研菓報 海洋温度差発電特 集, $50,9 \& 10$ (1986).

4) L.F. Lewis, L. Trimble, J. Bowers, Proceedings of Oceans '87, 397-402 (1987).

5) F. Kreith, D. Bharathan, J. Heat Transfer, 110, 522 (1988).

6) M. Reali, Energy, 6, 227-231 (19819).

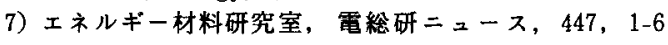
(1989).

8) M. de Gerloni, M. Reali, E. Drioli, G. Iorio, Sym. on Membranes and Membrane Process, Pergia (1982).

\section{迁 海中鉱物の電解被覆}

\section{熊田諴}

\section{1 まえがき}

電着技術（コーラル・プロセス）は，海水中に溶存し ている $\mathrm{Ca}^{2+}$ イオンや $\mathrm{Mg}^{2+}$ イオン（通常海水中には $\mathrm{Ca}^{2+}$ イオンが $300 \sim 400 \mathrm{ppm}, \mathrm{Mg}^{2+}$ イオンが 1200 ppm 含まれている）を電解により陰極面に $\mathrm{CaCO}_{3}$ や $\mathrm{Mg}(\mathrm{OH})_{2}$ を主成分とする電着物として析出させ, コン クリート状の構造物を海水中で構筑する技術 ${ }^{1)}$ である. この技術の応用として, 電着コーディングによる海洋構 造物や港湾施設の防食 (電着防食法) ${ }^{2)}$ のほか, 水産分 野の施設造成などがあげらる. 本稿では，はじめに電着 物の基本特性について述べ，次に電着技術の応用につい て紹介して, 海洋開発の今後の参考に供したい。なお, 本稿の表題の電解被覆は電着之同義語である.

\section{1 思策の原理}

\section{2 定前物の基本特性}

海水中に陽極（不溶性陽極）と陰極を浸漬し，直流電 源を介して電圧を負荷し電流密度 $0.2 \sim 0.7 \mathrm{~mA} / \mathrm{cm}^{\hat{z}}$ の直流電流を流す之, 陰極面に $\mathrm{CaCO}_{3}, \mathrm{Mg}(\mathrm{OH})_{2}$ な どの電着物が析出する (Fig. 1).

電着物の析出反応は電気化学反応過程と液相反応に分 けることができる (Table 1). 電気化学反応では陽極
と陰極の間に電圧を加え分極することによって (1)〜 (5) 式の反応が起こる.

これらの電気化学反応により陰極界面の極く近傍 (0.05 0.1 mm) で $\mathrm{OH}^{-}$の発生によりアルカリ性芬囲 気が形成され， $\mathrm{pH}$ が高くなる。この $\mathrm{pH}$ 変化により （6）（10）式に示す波相反応が生じ, 電着物 $\mathrm{CaCO}_{3}$, $\mathrm{Mg}(\mathrm{OH})_{2}$ が生成する. $\mathrm{CaCO}_{3}$ は $\mathrm{pH}$ 8 9 以上, $\mathrm{Mg}$

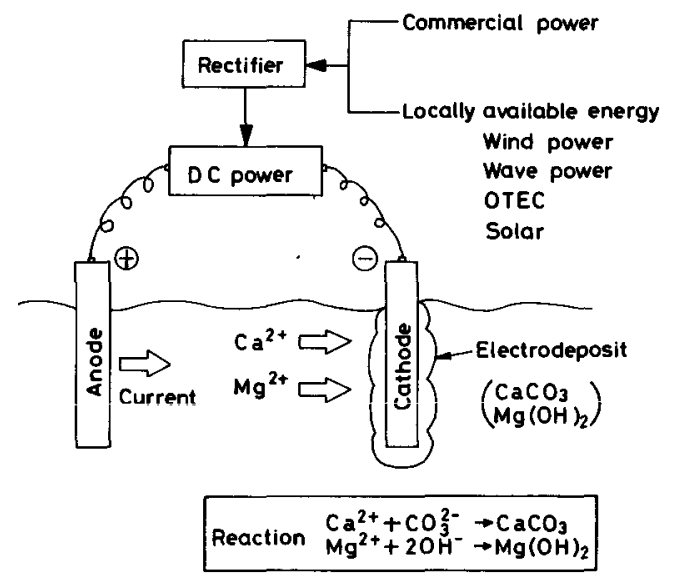

Fig. 1 Principle of electrodeposition system. 